\title{
Gallbladder Injury During Percutaneous Nephrolithotomy
}

\author{
Ramazan Kozan, ${ }^{1}$ Alp Yıldız, ${ }^{2}$ Osman Kurukahvecioğlu, ${ }^{2}$ Orhan Bayram²
}

\author{
'Department of General Surgery, \\ Eren Hospital, İstanbul, Turkey \\ ${ }^{2}$ Department of General Surgery, \\ Gazi University Faculty of Medicine, \\ Ankara, Turkey \\ Submitted: 13.07.2015 \\ Accepted: 14.09.2015 \\ Correspondence: Ramazan Kozan, \\ Eren Hastanesi, Kayışdağı Caddesi, \\ No: 57/A, Küçükbakkalköy, \\ Ataşehir, İstanbul, Turkey \\ E-mail: dr.kozan@hotmail.com \\ Keywords: Gallbladder \\ injury; laparoscopic \\ cholecystectomy; \\ percutaneous \\ nephrolithotomy.
}

\begin{abstract}
Percutaneous nephrolithotomy (PCNL) is an effective and minimally invasive method used for the treatment of kidney stones in selected patients. Some complications can occur with this method as in any surgical procedure. We report the laparoscopic diagnosis and treatment of a rare case of gallbladder perforation which occurred during percutaneous nephrolithotomy. Although it is a rare complication, biliary tract injury should be considered in patients with peritonitis after PCNL. Laparoscopic surgery can provide both diagnosis and minimally invasive treatment for cases in whom exact location of injury could not be determined with radiographic examinations.
\end{abstract}

\section{INTRODUCTION}

Percutaneous nephrolithotomy (PCNL) has almost wholly replaced open stone surgery in the treatment of urinary tract stone diseases. Despite its many advantages as a minimally invasive method, it should not be forgotten that various complications can occur with PCNL, as in every surgical procedure, and that these complications can create life-threatening conditions. The most frequently encountered PCNL complications are fever, extravasation, and hemorrhage necessitating blood transfusion. Septicemia, colon injury, and pleural injury are rarely encountered major complications. ${ }^{[I]}$ Biliary tract injuries are relatively rare and generally present with biliary peritonitis. Late diagnosis and treatment may cause these complications to have fatal consequences. The aim of the present study was to present the diagnostic process and treatment with minimally invasive surgery of gallbladder perforation that developed during PCNL.

\section{CASE REPORT}

PCNL had been performed on a 32-year-old male patient at another medical center for right nephrolithiasis. Procedure was terminated upon discovering bile material while trying to enter renal pelvis with I8-gauge needle. The patient, who developed defense in the abdomen after the intervention but no sign of rebound or tenderness, was monitored closely. On second postoperative day, patient's leucocyte count was $9300 / \mathrm{mm}^{3}$ and abdominal ultrasonography (US) was performed. Fluid in rectovesical space and paraduodenal space, and thickening of duodenum wall were detected. Patient was referred to our clinic at approximately 50th hour after PCNL. His vital signs were: temperature $36.6^{\circ} \mathrm{C}$, pulse rate 72 beats/minute, arterial blood pressure value $120 / 65 \mathrm{mmHg}$. On physical examination, induced defense and tenderness on deep palpation were present in the patient, whose general condition was good; rebound sign was not detected. Bilirubin values, and 
renal and liver function tests were within normal limits in the patient, whose leucocyte count was $13900 / \mathrm{mm}^{3}$. On emergency abdominal US, minimal fluid density was seen between bowel loops adjacent to second section of duodenum. Oral and intravenous contrast abdominopelvic computed tomography (CT) was performed. Free fluid reaching from pericholecystic and sub-hepatic space to the pelvis was observed. Moreover, hypodense linear line belonging to probable line of intervention, which passed the anterior and posterior segments of lower pole of right kidney, wall thickening throughout right urethra, increase in linear density in periurethral margin, and free fluid between the bowel loops in the pelvic region were detected (Figure I). Free air was not present in the abdomen. However, biliary tract injury could not be ruled out on CT. Therefore, magnetic resonance cholangiopancreatography (MRCP) was performed. Septate, lamellar fluid density was seen between gallbladder and liver bed, and between mucosa and muscular layer on the sac wall. Free fluid amid bowel loops from perihepatic, pericholecystic, and pericholedochal space was seen. However, a clear sign was not observed in support of biliary system damage (Figures $2 \mathrm{a}, \mathrm{b})$.

Bile content of intra-abdominal free fluid identified by radiological investigations was collected with 12-French percutaneous drainage catheter with the help of US for differential diagnosis of urinoma or hemorrhagic fluid. A total of $200 \mathrm{cc}$ of bile material not containing any particles was extracted. During 4-hour follow-up of the patient, another 700 cc of bilious fluid was drained. On examination, clinical picture was assessed as compatible with biliary peritonitis. Patient had developed rigidity on abdominal wall, and defense sign had become more evident. Diagnostic laparoscopy was planned as site of injury could not

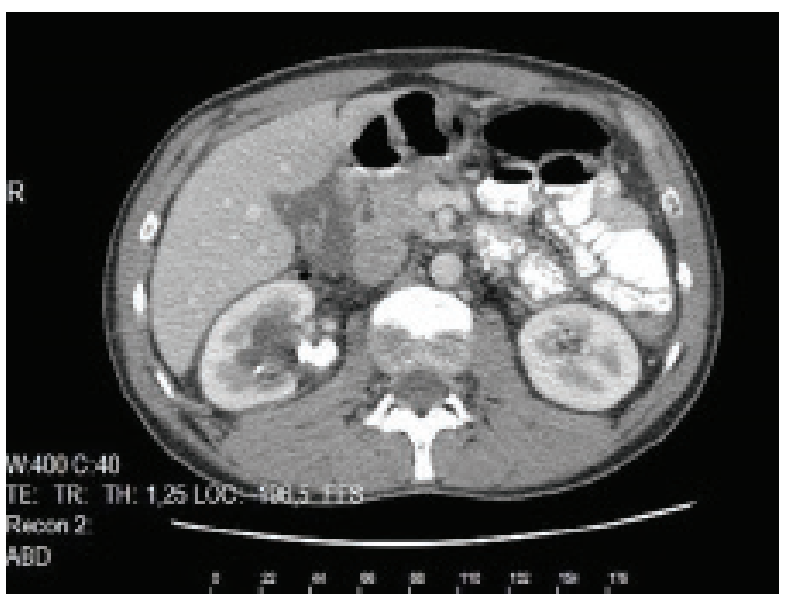

Figure 1. Dilated right renal pelvis and paraduodenal fluid on abdominal CT. be definitively located. Laparoscopic exploration revealed millimetric perforation site located almost adjacent to liver bed and at the level of the intersection of gallbladder corpus and infundibulum, and that active intraperitoneal biliary leakage was present (Figure 3). After having confirmed that there was no intra-abdominal organ injury, the sac was removed with an endobag by laparoscopic cholecystectomy. Bile contamination of peritoneal surfaces
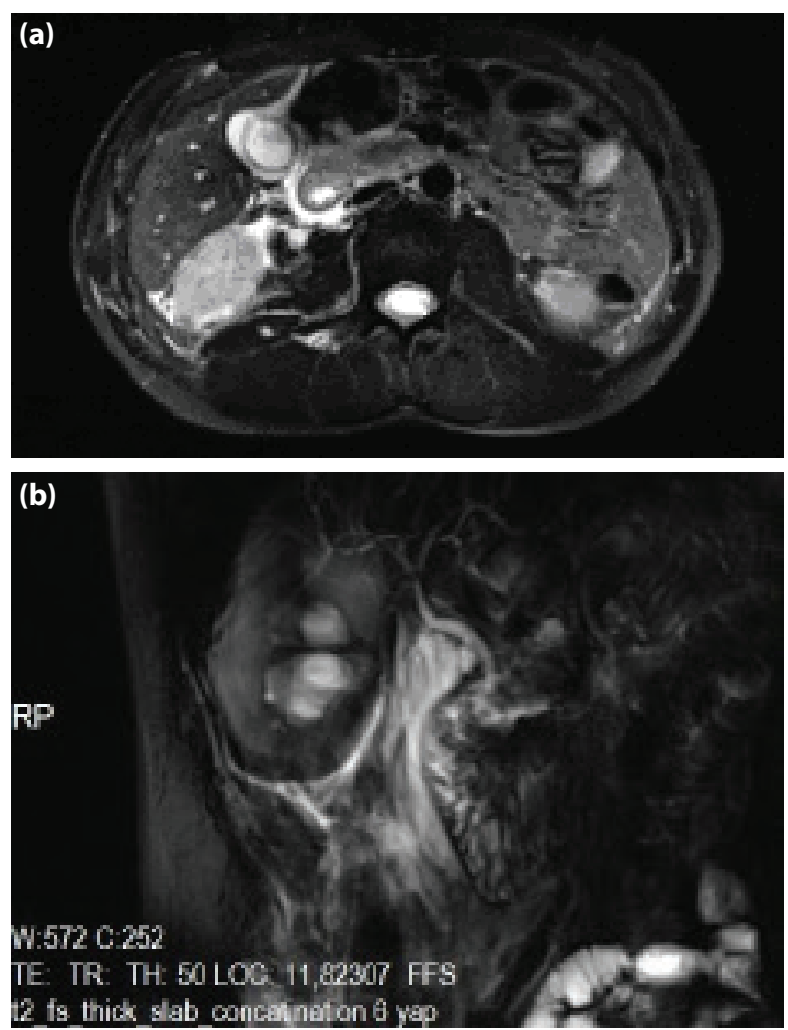

Figure 2. (a) Pericholecystic, paraduodenal, and perirenal fluid, as well as fluid on the sac wall seen on MRCP; (b) Biliary ductus system at the coronal section as observed on MRCP.

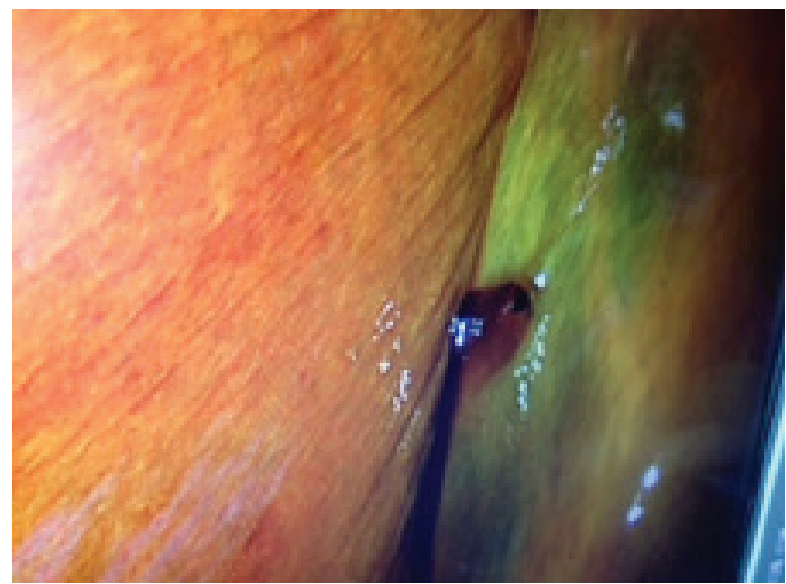

Figure 3. Intraoperative imaging of the injury to the gallbladder. 
was minimalized with irrigation and aspiration of abdomen with serum physiologic. Finally, a silicone drain that reached from right paracholic area to rectovesical space was used. Patient was discharged on third postoperative day without any problems. The patient's written consent was obtained for this study.

\section{DISCUSSION}

PCNL has become the standard treatment approach for kidney stones with ideal indications due to its advantages such as short length of hospital stay, short recovery time, small-size of the surgical cut, and high treatment success. However, it should not be ignored that there is the possibility of unwanted complications, just as there is in every invasive procedure. In studies with large series, rate of major complications has been reported as between $3.2 \%$ and $6.8 \% .^{[2,3]}$ Most frequently encountered complications are extravasation (7.2\%), need for blood transfusion (11.2\%$17.5 \%)$, and fever $(21 \%-32.1 \%)$. Septicemia $(0.3 \%-4.7 \%)$, colon injury $(0.2 \%-4.8 \%)$, and pleural injury $(0-3.1 \%)$ are rarely encountered major complications.[I] Visceral organ injuries are serious complications that, while rare, can be fatal. Incidence of colon perforation is less than $1 \%{ }^{[4]}$ As long as there is no hepatomegaly or splenomegaly, liver and spleen injuries are also quite rare. Though few in number, injuries to spleen, intestines and duodenum of intraperitoneal organs have also been reported. ${ }^{[5,6]}$ Cases of biliary tract injury after PCNL are very limited in the literature. These injuries need to be kept in mind, despite being rare complications.

When rare cases were analyzed, it was seen that a patient in whom acute abdominal signs developed after percutaneous nephrostomy performed with US was treated with laparotomy and cholecystectomy due to biliary peritonitis caused by gallbladder injury. ${ }^{[7]}$ In another patient with a history of gastric bypass and in whom biliary injury developed after PCNL, treatment was provided with subhepatic drainage catheter placed percutaneously and a cholecystostomy tube. ${ }^{[8]}$ Another case of gallbladder injury was treated similarly with laparoscopic cholecystectomy due to signs of peritoneal irritation and subhepatic and pericholecystic fluid seen on CT after PCNL. ${ }^{[9]}$

Laparoscopic surgery is a minimally invasive method that has significant advantages when compared to open surgery. ${ }^{[10]}$ Just as in the case currently presented, it is important that there is a treatment approach that ensures definitive diagnosis and provides treatment opportunities with minimally invasive procedures for intra-abdominal injuries where localization cannot be clearly determined despite many imaging techniques. Methods such as endoscopic retrograde cholangiopancreatography (ERCP) and percutaneous transhepatic cholangiography (PTC) are used with high success rates in the treatment of minor biliary leakage that occurs postoperatively. ${ }^{\left[{ }^{\prime \prime}\right]}$ Therefore, even though it is paramount that they are considered in the treatment of biliary injuries, they can only be considered among alternative treatment options in the presence of localized peritonitis, and when the injury is in the canal system and an optimal type. Late treatment can lead to worsening of the clinical picture of the patient by causing the development of ileus and sepsis due to biliary peritonitis. ${ }^{[12]}$ Hence, laparoscopic surgery should be the primary approach in ideal cases, since it provides for early diagnosis and an opportunity for minimally invasive surgery.

\section{Conclusion}

The possibility of biliary peritonitis, though very rare, must be kept in mind for patients who develop peritoneum irritation signs after percutaneous nephrostomy or PCNL. Laparoscopic approach should be considered among all primary options due to the fact that it ensures definitive diagnosis and treatment opportunity with minimally invasive surgery in cases of intraperitoneal organ injuries, such as gallbladder injuries, which can lead to peritonitis.

\section{REFERENCES}

1. Michel MS, Trojan L, Rassweiler JJ. Complications in percutaneous nephrolithotomy. Eur Urol 2007;51:899-906.

2. Segura JW, Patterson DE, LeRoy AJ, Williams HJ Jr, Barrett DM, Benson RC Jr, et al. Percutaneous removal of kidney stones: review of 1,000 cases. J Urol 1985;134:1077-81.

3. Segura JW, Preminger GM, Assimos DG, Dretler SP, Kahn RI, Lingeman JE, et al. Nephrolithiasis Clinical Guidelines Panel summary report on the management of staghorn calculi. The American Urological Association Nephrolithiasis Clinical Guidelines Panel. J Urol 1994;151:1648-51.

4. Gupta M, Ost MC, Shah JB, Mcdougal EM, Smith AD. Percutaneous management of the upper urinary tract. In: Wein AJ, Kavoussi LR, Novick AC, Partin AW, Craig AP, editors. Campbell-Walsh urology. 9th ed., Volum 2. Philadelphia: Saunders Elsevier; 2007. p. 1526-62.

5. Santiago L, Bellman GC, Murphy J, Tan L. Small bowel and splenic injury during percutaneous renal surgery. J Urol 1998;159:2071-3.

6. Kumar A, Banerjee GK, Tewari A, Srivastava A. Isolated duodenal injury during relook percutaneous nephrolithotomy. Br J Urol 1994;74:382-3.

7. Kontothanassis D, Bissas A. Biliary peritonitis complicating percutaneous nephrostomy. Int Urol Nephrol 1997;29:529-31.

8. Rahnemai-Azar AA, Rahnemaiazar AA, Naghshizadian R, Cohen $\mathrm{JH}$, Naghshizadian I, Gilchrist BF, et al. Minimally invasive management of biliary tract injury following percutaneous nephrolithotomy. Nephrourol Mon 2014;6:19943. 
9. Fisher MB, Bianco FJ Jr, Carlin AM, Triest JA. Biliary peritonitis complicating percutaneous nephrolithomy requiring laparoscopic cholecystectomy. J Urol 2004;171(2 Pt 1):791-2.

10. McMahon AJ, Baxter JN, Kenny G, O'Dwyer PJ. Ventilatory and blood gas changes during laparoscopic and open cholecystectomy. $\mathrm{Br}$ J Surg 1993;80:1252-4.
11. Eum YO, Park JK, Chun J, Lee SH, Ryu JK, Kim YT, et al. Non-surgical treatment of post-surgical bile duct injury: clinical implications and outcomes. World J Gastroenterol 2014;20:6924-31.

12. Moossa AR, Easter DW, Van Sonnenberg E, Casola G, D'Agostino H. Laparoscopic injuries to the bile duct. A cause for concern. Ann Surg 1992;215:203-8.

\section{Perkütan Nefrolitotomi Sırasında Gelişen Safra Kesesi Yaralanması}

Perkütan nefrolitotomi (PNL) uygun hastalarda böbrek taşı tedavisinde kullanılan etkin ve minimal invaziv bir yöntemdir. Her cerrahi işlemde olduğu gibi bu yöntemde de bazı komplikasyonların oluşabilmesi söz konusudur. Bu yazıda, oldukça nadir görülen perkütan nefrolitotomi esnasında oluşmuş safra kesesi perforasyonu olgusunun laparoskopik tanı ve tedavisi sunuldu. İşlem sonrası karında peritonit bulguları gelişen hastalarda ender bir komplikasyon olsa da biliyer sistem yaralanması ihtimali göz önünde tutulmalıdır. Radyolojik yöntemler ile yaralanmanın tam olarak lokalize edilemediği vakalarda laparoskopik yaklaşım hem kesin tanı hem de etkin minimal invaziv tedavi olanağı verebilmektedir.

Anahtar Sözcükler: Safra kesesi yaralanması; laparoskopik kolesistektomi; perkütan nefrolitotomi. 